University of Wollongong

Research Online

Australian Institute for Innovative Materials -

Papers

Australian Institute for Innovative Materials

$1-1-2013$

\title{
ZnO-doped LiFePO4 cathode material for lithium-ion battery fabricated by hydrothermal method
}

\author{
Yemin $\mathrm{Hu}$ \\ Shanghai University \\ Jun Yao \\ Shanghai University \\ Zhe Zhao \\ Shanghai University \\ Mingyuan Zhu \\ Shanghai University \\ Ying Li \\ Shanghai University
}

See next page for additional authors

Follow this and additional works at: https://ro.uow.edu.au/aiimpapers

Part of the Engineering Commons, and the Physical Sciences and Mathematics Commons

Research Online is the open access institutional repository for the University of Wollongong. For further information contact the UOW Library: research-pubs@uow.edu.au 


\title{
ZnO-doped LiFePO4 cathode material for lithium-ion battery fabricated by hydrothermal method
}

\author{
Abstract \\ LiFePO4 particles doped with zinc oxide was synthesized via a hydrothermal route and used as cathode \\ material for lithium-ion battery. Sample of preferable shape and structure was obtained by a concise and \\ efficient process. ZnO doping into the LiFePO4 matrix was positively confirmed by the results of X-ray \\ diffraction (XRD); high-resolution transmission electron microscopy (HRTEM); energy dispersive \\ spectrometer (EDS), and X-ray photoelectron spectroscopy (XPS). LiFePO4 doped with ZnO tends to form \\ nanometer-size and homogeneous particles, which can improve markedly the performance and stability \\ of charge-discharge cycle. A specific discharge capacity of ZnO-doped LiFePO4 at $132.3 \mathrm{mAh}$ g-1 was \\ achieved, with $1.8 \%$ decrease after 100 cycles. Based on the cyclic voltammetry (CV) and electrochemical \\ impedance spectroscopy (EIS) results, it has further shown that ZnO doping effectively reduces the \\ impacts of polarization and transfer resistance during electrochemical processes.

\section{Keywords} \\ hydrothermal, fabricated, battery, ion, lithium, material, method, cathode, zno, lifepo4, doped \\ Disciplines \\ Engineering | Physical Sciences and Mathematics

\section{Publication Details} \\ Hu, Y., Yao, J., Zhao, Z., Zhu, M., Li, Y., Jin, H., Zhao, H. and Wang, J. (2013). ZnO-doped LiFePO4 cathode \\ material for lithium-ion battery fabricated by hydrothermal method. Materials Chemistry and Physics, 141 \\ (2-3), 835-841.
}

\section{Authors}

Yemin Hu, Jun Yao, Zhe Zhao, Mingyuan Zhu, Ying Li, Hongming Jin, Huijun Zhao, and Jiazhao Wang 


\title{
ZnO-doped $\mathrm{LiFePO}_{4}$ Cathode Material for Lithium Ion Battery Fabricated by Hydrothermal Method
}

\author{
Yemin $\mathrm{Hu}^{1}{ }^{1}$, Jun Yao ${ }^{1}$, Zhe Zhao ${ }^{1}$, Mingyuan Zhu ${ }^{1}$, Ying $\mathrm{Li}^{1}$, Hongming Jin ${ }^{1}$, Huijun Zhao ${ }^{2}$, \\ Jiazhao Wang ${ }^{3}$
}

1 Laboratory for Microstructures/School of Materials Science and Engineering, Shanghai University, Shanghai, 200072, China

2 Centre for Clean Environment and Energy, Griffith School of Environment, Griffith University, Queensland 4222, Australia

3 Institute for Superconducting and Electronic Materials, Innovation Campus, University of Wollongong, NSW 2500, Australia

\begin{abstract}
:
$\mathrm{LiFePO}_{4}$ particles doped with zinc oxide was synthesized via a hydrothermal route and used as cathode material for lithium ion battery. Sample of preferable shape and structure was obtained by a concise and efficient process. $\mathrm{ZnO}$ doping into the $\mathrm{LiFePO}_{4}$ matrix was positively confirmed by the results of X-ray diffraction (XRD); high-resolution transmission electron microscopy (HRTEM); energy dispersive spectrometer (EDS), and X-ray photoelectron spectroscopy (XPS). $\mathrm{LiFePO}_{4}$ doped with $\mathrm{ZnO}$ tends to form nanometer-size and homogeneous particles, which can improve markedly the performance and stability of charge-discharge cycle. A specific discharge
\end{abstract}

\footnotetext{
* Corresponding author. Tel.: +862156336107.
}

E-mail addresses: huyemin@shu.edu.cn (Y.M. Hu). 
capacity of $\mathrm{ZnO}$-doped $\mathrm{LiFePO}_{4}$ at $132.3 \mathrm{mAh} / \mathrm{g}$ was achieved, with $1.8 \%$ decrease after 100 cycles. Based on the cyclic voltammetry (CV) and electrochemical impedance spectroscopy (EIS) results, it has further shown that $\mathrm{ZnO}$ doping effectively reduces the impacts of polarization and transfer resistance during electrochemical processes.

\section{Key words:}

inorganic compounds; oxides; chemical synthesis; X-ray photo-emission spectroscopy (XPS); electrochemical properties

\section{Introduction}

The lithium ion battery assembled with phosphor-olivine $\mathrm{LiFePO}_{4}$ (LFP) based cathode material possess long cycle life and high service voltage, and have been recognized as one of the most attractive power supplies for electric vehicle and hybrid electric vehicle $[1,2]$. It is well known that the ionic diffusion and electron conductivities can be remarkably improved by doping appropriate functional material to LFP, and the ameliorated microstructure is achieved which shortens the transmission distance of lithium ions and prevents the collapse of the crystal lattice [3-7]. And to prepare $\mathrm{LiFePO}_{4}$ at a low cost and efficiently, the hydrothermal synthesis is well studied by many researchers [8-16]. Their results demonstrate that the particle size and conductivity of LFP can be controlled by appropriate additive, such as CTAB, ascorbic acid and carbon nanotube under hydrothermal conditions and the appropriate temperature is necessary. H.K. Liu et al. mixed LFP with commercial $\mathrm{ZnO}$ powders through solid route and considered that the doped zinc ions protect the LFP crystal from shrinking [17]. This kind of "pillar" effect provides more space for the movement of lithium ions. Consequently, its conductivity is enhanced and the 
lithium-ion diffusion coefficient is boosted after doping. These favorable changes are beneficial for the electrochemical performance of LFP, including the discharge capacity and rate capability. This paper presents our recent study about $\mathrm{ZnO}$ doped LFP fabricated through a convenient hydrothermal route which is used as cathode material of lithium ion battery. The doping effect of $\mathrm{ZnO}$ on the microstructure and the electrochemical properties of LFP were also involved.

\section{Experimental}

\subsection{Sample preparation}

In this study, starting materials are $\mathrm{LiOH}, \mathrm{Zn}(\mathrm{Ac})_{2} \cdot 2 \mathrm{H}_{2} \mathrm{O}, \mathrm{FeSO}_{4} \cdot 7 \mathrm{H}_{2} \mathrm{O}$ and $\mathrm{H}_{3} \mathrm{PO}_{4}$. All the chemicals (AR grade) were purchased from Sinopharm Chemical Reagent.

The $\mathrm{ZnO}$ precursor was prepared by adding $\mathrm{LiOH}$ solution to $\mathrm{Zn}(\mathrm{Ac})_{2}$ solution under magnetic stirring for $1 \mathrm{~h}$ in ice-water bath to form $\mathrm{Zn}(\mathrm{OH})_{2}$ precipitations, which would generate $\mathrm{ZnO}$ in the following hydrothermal reaction. The molar ratio of $\mathrm{Zn}^{2+}: \mathrm{OH}^{-}$in the above solution was 1:2.

To prepare the LFP precursor, $\mathrm{LiOH}$ solution and $\mathrm{H}_{3} \mathrm{PO}_{4}$ were mixed in a beaker by magnetic stirring for $2 \mathrm{~h}$ in ice-water bath to obtain $\mathrm{Li}_{3} \mathrm{PO}_{4}$ white colloids. Then the colloidal $\mathrm{Li}_{3} \mathrm{PO}_{4}$ were mixed with the $\mathrm{ZnO}$ precursor and magnetic stirred for 30min, followed by adding $\mathrm{FeSO}_{4}$ solution to form a dark green mixture under nitrogen bubbling. The molar ratio of $\mathrm{Li}^{+}: \mathrm{PO}_{4}^{3+}: \mathrm{Fe}^{2+}$ was 3.05:1:1, and the nominal concentration of $\mathrm{ZnO}$ in $\mathrm{LFP}$ was $2.5 \mathrm{wt} \%$ from which we can learn that the total amount of the $\mathrm{Zn}$ (II) ions is $2.01 \mathrm{wt} \%$ in the doped sample. Next, the mixture was quickly transferred into an autoclave, which was sealed and heated at $180 \square$ for $16 \mathrm{~h}$. Subsequently, the autoclave was cooled to room temperature and the reaction mixture was filtered. The greyish precipitated residue was washed several times with de-ionized water under suction pressure. Finally, the filter cake was dried in a vacuum oven at $120 \square$ for $12 \mathrm{~h}$. Samples prepared from the 
above process (described by chemical equation 1 and 2) were classified as $\mathrm{ZnO-doped} \mathrm{LFP.} \mathrm{For}$ comparison, pure LFP samples were prepared in the same manner without adding $\mathrm{ZnO}$ precursor (equation 1). Though the reaction mechanism for the hydrothermal synthesis of $\mathrm{LiFePO}_{4}$ is complicated $[14,15]$, some of the possible chemical reaction equations were shown as below.

$$
\begin{gathered}
3 \mathrm{LiOH}+\mathrm{H}_{3} \mathrm{PO}_{4}+\mathrm{FeSO}_{4} \rightarrow \mathrm{LiFePO}_{4}+\mathrm{Li}_{2} \mathrm{SO}_{4}+3 \mathrm{H}_{2} \mathrm{O} \\
2 \mathrm{LiOH}+\mathrm{Zn}(\mathrm{Ac})_{2} \rightarrow \mathrm{ZnO}+2 \mathrm{LiAc}+\mathrm{H}_{2} \mathrm{O}
\end{gathered}
$$

\subsection{Characterization and electrochemical measurements}

The samples were characterized by X-ray diffraction (XRD) with $\mathrm{Cu} \mathrm{K} \alpha_{1}$ radiation; scanning electron microscopy (SEM, JEOL JSM6700F); high-resolution transmission electron microscope (HRTEM, JOEL JEM-2010F); energy dispersive spectrometer (EDS, Mn $\mathrm{K} \alpha<136 \mathrm{eV}$ ) and X-ray photoelectron spectroscopy (XPS, Thermo ESCALAB 250) with focused monochromatic Al Ka radiation $(1486.6 \mathrm{eV})$.

Electrochemical performances of the samples were carried out using CR2016-type coin cells. The cathode for lithium ion battery was prepared by mixing the as-synthesized $\mathrm{ZnO-doped} \mathrm{LFP}$ powder, acetylene black, and Teflon powder in a weight ratio of 80:15:5 in an agate mortar to form a paste. And the paste was dried in a vacuum oven at $120 \square$ for $12 \mathrm{~h}$ and rolled into a thin film. Then the film was cut into small discs (about $0.25 \mathrm{~cm}^{2}$ ) and used as the cathodes. The coin cells and the lithium metal anode were assembled in an argon-filled glove box with $1 \mathrm{M} \mathrm{LiPF}_{6}$ in ethylene carbonate $(\mathrm{EC})$ : dimethyl carbonate $(\mathrm{DMC})=1: 1$ as the electrolyte; Celgard C2500 membrane as the separator; and foam nickel as filler material. Cells were charged and discharged in cycles with voltage in 2.5 4.3 $\mathrm{V}$ range, measured by LAND battery tester (Wuhan LAND Electronics Co. Ltd., China) at room temperature $\left(25^{\circ} \mathrm{C}\right)$. The curves of cyclic voltammetry $(\mathrm{CV}$, 
1030B, Shanghai Chenhua Instrument Ltd, China) were carried out at $0.1 \mathrm{mV} \cdot \mathrm{s}^{-1}$ within the range of $2.3 \sim 4.5 \mathrm{~V}$ at room temperature $\left(\sim 25^{\circ} \mathrm{C}\right)$. The electrochemical impedance spectroscopy (EIS) is conducted on the Solartron1287-1255B electrochemical workstation. The amplitude of the input AC signal is $5 \mathrm{mV}$, and the frequency range is set between $0.01 \mathrm{~Hz}$ and $100 \mathrm{kHz}$.

\section{Results and discussion}

\subsection{Structural Characteristics of $\mathrm{ZnO}$-doped $\mathrm{LiFePO}_{4}$}

Fig.1 displays $\mathrm{X}$ - ray diffractions of $\mathrm{ZnO}$-doped and un-doped LFP samples. The narrow and sharp peaks indicate that both two samples crystallized well and agreed with an ordered olivine-type structure indexed to the orthorhombic Pnmb space group (JCPDS Card No. 83-2092). Also, the patterns in Fig.1 show the presence of ZnO phase (JCPDS Card No. 89-1397) in ZnO-doped LFP sample as confirmed by the peaks at $34.4^{\circ}, 56.6^{\circ}, 67.9^{\circ}$ and others, respectively.

Furthermore, the unit cell parameters of the samples are calculated by using MDI Jade software and listed in table.1. For the sample of $\mathrm{ZnO}$-doped $\mathrm{LiFePO}_{4}$, there are some extensions along a, $\mathrm{b}$ and c-axes. The increment of total lattice volume is about $1.14 \%$. It infers that some $\mathrm{Zn}$ (II) ions might be doped into $\mathrm{LiFePO}_{4}$ crystal lattice successfully. And with the pillar effect [17], this structural enlargement would be beneficial to lithium-ion diffusion.

As researched by J.J. Chen's group [12], it is indicated that around 0.14 zinc was substituted for iron, giving $\mathrm{LiFe}_{0.86} \mathrm{Zn}_{0.14} \mathrm{PO}_{4}$ when $20 \%$ zinc was in the reaction medium. A Rietveld analysis also indicated zinc on the iron site and not on the lithium site. Their study showed that the lattice volume became smaller with the formation of $\mathrm{LiZnPO}_{4}$ phase, which is opposite to our study result. It inferred that in our study, the zinc ions possibly do not exist in the form of $\mathrm{LiZnPO}_{4}$ due 
to the different doping process and different zinc source.

The SEM images of ZnO-doped and un-doped LFP are presented in Fig.2. In Fig.2 (a) it shows that $\mathrm{ZnO}$-doped sample formed fine and homogeneous particles with the size of 300-400 nanometers. In Fig.2 (b) the size of pure LFP with slice shape were shown to be much larger than that of doped one, with sub micrometer grade. It infers that $\mathrm{ZnO}$ doping in the LFP lattice may promote the nucleation process and decrease the particle size markedly during the reactions. Similar phenomenon was observed by X.Y. Kang et al. [18]. They thought that the reason for $\mathrm{ZnO}$-doped LFP/C samples with smaller particles was that $\mathrm{Zn}$ ions in the solid solution inhibit particles to conglomerate and form secondary particles even after calcinations. R.S. Guo and his colleagues [19] used sol-gel and freeze-drying methods to obtain LFP precursor xerogel. Then the precursor was calcined in a reductive atmosphere and ground with a mortar and pestle. They also indicate that $\mathrm{ZnO} / \mathrm{C}$-LFP has a relative lower particle size. The size decrease of LFP particles owing to $\mathrm{ZnO}$ doping leads to the efficient depth of charge and enhances the overall battery performance.

TEM images of samples were illustrated in Fig. 3(a) and (b). It can be seen that the size of doped sample is about $300 \mathrm{~nm}$ in width and $400 \mathrm{~nm}$ in length, while the size of un-doped sample is about $700 \mathrm{~nm}$ in width and $1.1 \mu \mathrm{m}$ in length. The composition of ZnO-doped LFP was identified by EDS as shown in Fig.3(c). $\mathrm{Zn}$ is clearly observed in the doped sample and no impurity was detected except $\mathrm{Cu}$, which was introduced from the copper grid for TEM study.

Fig. 4 exhibits clear lattice fringes of both un-doped and doped LFP, indicating their single crystallinity nature. It also exhibits typical fast Fourier transformation (FFT) patterns of orthorhombic LFP viewed along [100] direction. The FFT patterns confirm that the LFP particle is 
a single crystal. Because of the orthorhombic structure of LFP crystal, the value of lattice parameter $b$ equals to the width of neighboring lattice fringes corresponding to the (010) planes. The numerical values of $b^{*}$ and $c^{*}$ measured in Fig. 4 (a) and (b) with the help of Digital Micrograph software and the values of $b$ of doped and un-doped LFP indicated by the reciprocity relation with $b^{*}$ are shown in Table 1 . The $b / c$ ratio of un-doped LFP crystal, which equals to the $c^{*} / b^{*}$ ratio by the reciprocity relation, is also indicated in Table 1 . It is learned from the table that the FFT results of doped LFP are almost the same with the un-doped one except that the values of $b$ and $b / c$ of doped one are a little higher than un-doped one. This fact indicates that the interplanar crystal spacing along (010) becomes widening after doping, which is identical to the phenomenon of crystal volume increment that is obtained from the XRD analysis (Table 1) and proves the pillar effect of $\mathrm{ZnO}$ further.

To further investigate the state of zinc element in the ZnO-doped LFP sample, XPS analyses were carried out and the results are shown in Fig. 5. The XPS survey spectra are generally the same, except the scope from $1019 \mathrm{eV}$ to $1027 \mathrm{eV}$ in the curve of $\mathrm{ZnO}$-doped sample, which exhibits the peak of $\mathrm{Zn} 2 \mathrm{p} 3 / 2$. The detailed and fitting curves of $\mathrm{Zn}(2 \mathrm{p} 3 / 2)$ for the $\mathrm{ZnO}$-doped LFP are magnified in the Fig. 5(b). From the figure, there are three main fitting peaks of binding energy, which are located at $1021.3 \mathrm{eV}, 1022.5 \mathrm{eV}$ and $1023.7 \mathrm{eV}$, respectively. The first peak is close to that of $\mathrm{ZnFe}_{2} \mathrm{O}_{4}(1021.4 \mathrm{eV}$, Ref. [20]). It infers that some $\mathrm{Zn}$ ions doped into the crystal lattice of LFP are close to $\mathrm{FeO}_{6}$ atomic group, and impacted by the $\mathrm{FeO}_{6}$ atomic group. The second peak agrees well with the reported value of $\mathrm{ZnO}$ (1022.5 eV, Ref. [21]), which indicates the existence of $\mathrm{ZnO}$. The binding energy of Zinc compounds were generally impacted by strong electronegative halides, such as $\mathrm{Br}, \mathrm{Cl}$. It is known that the binding energy of $\mathrm{Zn}$ ion in $\mathrm{ZnBr}_{2}$ is $1023.4 \mathrm{eV}$ [22], 
and in $\mathrm{ZnCl}_{2}$ is $1023.7 \mathrm{eV}$ [20]. It can be inferred that $\mathrm{PO}_{4}{ }^{3-}$ anion in the lattice of LFP would have similar effect on binding energy of nearby $\mathrm{Zn}$ ions, and thus the third peak shifts to $1023.7 \mathrm{eV}$. The atomic percentage of zinc element is $0.53 \%$ as obtained from the XPS test. As the nominal mass percentage of zinc element in our doped LFP sample is $2.01 \mathrm{wt} \%$, which was mentioned in the experimental section, it's easy to calculate that the nominal atomic percentage of zinc element is $0.71 \%$. The calculated result is a little higher than the XPS result possibly due to the loss of sample during the suction filtration process. Table 2 shows the specific results of XPS quantitative analysis obtained by peak fitting. It is learned from the table that the amount of $\mathrm{Zn}$ ions indicated by peak 1 and peak 3 is about $22.3 \%$ and $20.1 \%$ of the total zinc amount, respectively. And the amount of $\mathrm{Zn}$ ions indicated by peak 2 which exist in the form of $\mathrm{ZnO}$ is about $57.5 \%$ of the total. So it can be confirmed that $\mathrm{Zn}$ ions are doped into the crystal lattice of LFP successfully.

\subsection{Performances of $\mathrm{ZnO}$-doped $\mathrm{LiFePO}_{4}$ cathodes}

Fig.6 shows the charge-discharge profiles of $\mathrm{ZnO}$-doped and undoped LFP between 4.3 and $2.5 \mathrm{~V}$ at a current rate of $0.1 \mathrm{C}(1 \mathrm{C}=170 \mathrm{mAh} / \mathrm{g})$ for the cycle of $1^{\text {st }}($ Fig. $6 \mathrm{a}), 50^{\text {th }}$ (Fig. $\left.6 \mathrm{~b}\right)$ and $100^{\text {th }}$ (Fig. 6c), respectively. It is clearly confirmed that the capacity of the cell without $\mathrm{ZnO}$ faded more quickly than that of the cell containing $\mathrm{ZnO}$. The voltage profiles of $\mathrm{ZnO}$-doped sample exhibit flatter charge-discharge plateaus than those of the un-doped LFP. And the differences between the charge-discharge voltages do not change with the increase of the cycle number. While that of un-doped LFP performance changes markedly, which means the polarization for un-doped sample become increasingly obvious. In addition, it can be seen that the irreversible capacity of ZnO-doped sample has only a little loss and the charge-discharge curves are almost the same from 
$50^{\text {th }}$ to $100^{\text {th }}$ cycles, which indicates that the kinetics of the LFP is indeed improved due to the enhanced electronic conductivity, which is resulted from $\mathrm{ZnO}$-doping. And the sample performs much more stable during the charge-discharge processes.

The cycle performances for ZnO-doped and undoped LFP at 0.1C-rate are shown in Fig.7. From the figure, the initial discharge capacity of $\mathrm{ZnO}$ free LFP is $127.2 \mathrm{mAh} \cdot \mathrm{g}^{-1}$, and it is only $66.9 \mathrm{mAh} \cdot \mathrm{g}^{-1}$ after 100 cycles. The decay is more than $47.4 \%$ comparing to the initial cycle. While ZnO-doped LFP has the capacity of $132.3 \mathrm{mAh} \cdot \mathrm{g}^{-1}$ for the first discharge, and maintains at 129.9 $\mathrm{mAh} \cdot \mathrm{g}^{-1}$ after 100 cycles, which is $98.2 \%$ of the initial capacity. The capacity-keeping performance of the doped sample is more stable than that of un-doped one. And similar results were reported in Liu et al.'s paper [17].

Fig. 8 shows the cyclic curves of $\mathrm{ZnO}$-doped and undoped LFP which were charged at $0.1 \mathrm{C}$, while discharged under various current rates $(0.1 \mathrm{C}, 0.5 \mathrm{C}, 1 \mathrm{C}$ and $10 \mathrm{C})$ at room temperature. It can be seen that the capacities decreased along with the increased current rate. It is because higher current rate means more lithium ions extract and reinsertion during relatively short time. When lithium ion migration can't meet the requirement, the discharge capacity will decay significantly. For example, in the final cycle of each stage, the specific discharge capacities of $\mathrm{ZnO}$-doped sample are $129.9 \mathrm{mAh} \cdot \mathrm{g}^{-1}, 94.2 \mathrm{mAh} \cdot \mathrm{g}^{-1}, 80 \mathrm{mAh} \cdot \mathrm{g}^{-1}$ and $25.8 \mathrm{mAh} \cdot \mathrm{g}^{-1}(98.2 \%, 71.2 \%, 60.5 \%$ and 19.5 $\%$ of the initial capacity, respectively) at the different discharged C-rate of $0.1 \mathrm{C}, 0.5 \mathrm{C}, 1 \mathrm{C}$ and $10 \mathrm{C}$, respectively. The much higher capacity of the doped sample comparing to the un-doped sample indicates that the $\mathrm{ZnO}$-doped sample performed much better in high rate discharge. This improvement of performance is beneficial to the lithium ion battery applications as power cell. The performance improvement of $\mathrm{ZnO}$-doped sample may be explained by the special 
morphology change, such as finer and more homogenous particles, which keep lattices from being collapsed during the process of lithium ions migration that may ruin the crystal lattice structure through long cycle and high C-rate charging and discharging [17]. Also, a small quantity of $\mathrm{ZnO}$ will improve conductivity distributing in LFP particles to give higher electronic transmission [23]. Table 3 gives a list of research results about high performance LFP published in recent years. Comparing to our research we can find that most of the initial capacities and cyclic performance at high rates of the C-coated LFP are much better than the ZnO-coated LFP. However, the cyclic performance of $\mathrm{ZnO}$-coated LFP at low rate is comparable to the C-coated LFP. And it's confirmed that the ZnO-coated LFP has a higher initial capacity and cyclic performance compared with the un-doped LFP whose performance was investigated by other researchers.

Fig.9 illustrates the results of cyclic voltammetry tests, which were tested at a scan rate of 0.1 $\mathrm{mV} \cdot \mathrm{s}^{-1}$ between $2.3 \mathrm{~V}$ and $4.5 \mathrm{~V}$. Each sample exhibits a group of typical curves composed by a pair of major redox peaks $\left(\mathrm{Li} / \mathrm{Li}^{+}\right)$centered from 3.25 to $3.75 \mathrm{~V}$. The potential difference between the anodic and cathodic peaks is always representative of the kinetics, especially considering that the electrochemical processes involve diffusion of lithium ions and electron transfer between different solid phases, $\mathrm{LFP}$ and $\mathrm{FePO}_{4}$ [33]. The ZnO-doped LFP shows much sharper oxidation-reduction peaks and much smaller potential gap $(\Delta \mathrm{V})$ than $\mathrm{ZnO}$ free LFP material, which means higher diffusion rate of $\mathrm{Li}^{+}$and electronic conductivity. The well defined peaks and symmetrical shape of CVs confirm that the crystal lattices of $\mathrm{ZnO}$-doped LFP do not change while lithium ions extracting from $\mathrm{LFP}$ and inserting into $\mathrm{FePO}_{4}$ [17]. It means that $\mathrm{ZnO}$-doping improves markedly the reversibility for charge-discharge during electrochemical reactions.

In order to deeply compare and understand the influence of $\mathrm{ZnO}$ on LFP matrix, the 
electrochemical impedance spectra (EIS) measurements, which can accurately reflect the cathode material's electrochemical characters $[34,35]$, were carried out in the frequency range from $0.01 \mathrm{~Hz}$ to $100 \mathrm{kHz}$ in both cells after one charge-discharge cycle. The EIS data fitted by the software of ZSimpWin are shown in the insert of Fig.10. The Nyquist plot of the doped sample showed two semicircles at medium-high and low frequencies, while the un-doped sample did not show as obvious. These EIS patterns can be well fitted by an equivalent circuit in the insert of Fig.10. Where, $\mathrm{R}_{\mathrm{e}}$ is bulk resistance reflecting the electric conductivity of the electrolyte, separator, and electrode; $\mathrm{R}_{\mathrm{SEI}}$ and $\mathrm{C}_{\mathrm{SEI}}$ are resistance and capacitance of the solid-state interface layer formed on surface of electrode, which corresponds to the semicircle at high frequency; $\mathrm{R}_{\mathrm{ct}}$ and $\mathrm{C}_{\mathrm{dl}}$ are charge-transfer resistance and it is related to double-layer capacitance between electrode and electrolyte, which corresponds to the semicircle at medium frequency; $Z_{\mathrm{W}}$ is Warburg impedance, related to the lithium ions diffusion in the active material, which is indicated at the low frequency [34]. The corresponding values were listed as shown in Table 4. The $R_{e}$ values of different cells are almost the same. The $R_{S E I}$ values are smaller than the $R_{c t}$ values suggesting that the electrochemical performance is mainly influenced by the charge transfer resistance. For example, the values of $\mathrm{R}_{\mathrm{SEI}}$ are 59.300 and $43.825 \Omega$, and the $\mathrm{R}_{\mathrm{ct}}$ values are 87.325 and $53.925 \Omega$, respectively. And also, it indicates that the charge-transfer resistance of LFP with $\mathrm{ZnO}$ is lower than that of LFP without $\mathrm{ZnO}$. Therefore, based on the results in Fig. 10, we can conclude that the LFP material doped with $\mathrm{ZnO}$ becomes more conductive, which is also confirmed by the cell performance from Fig. 6, Fig. 7, Fig. 8 and Fig. 9.

\section{Conclusion}


It has demonstrated that an effective, simple and concise hydrothermal synthesis allowed to prepare well-crystallized ZnO-doped LFP powder with good properties as the cathode for lithium ion battery. $\mathrm{ZnO}$ doping helps LFP to form homogeneous and smaller particles to shorten the path of lithium ion migration, and expands the crystal lattice which makes lithium ions intercalate/de-intercalate easily. The $\mathrm{CV}$ and EIS analyses show that $\mathrm{ZnO}$ effectively weakens electrochemical polarization and resistance, making lithium ions smoothly passed through electrode material. Comparing with $\mathrm{ZnO}$ free LFP sample, these favorable changes are beneficial for the electrochemical performance of LFP, such as charge and discharge capacities, and improves cycling behavior and reversibility significantly.

\section{Acknowledgements}

Financial support was provided by Shanghai Science and Technology Commission (11nm0501600, 09dz1203602) and Shanghai Leading Academic Discipline Project (S30107). The authors also thank Researcher Jin and Chu at Shanghai University; Prof. Yang, and graduated students Miss Gao and Mr. Liu at Changshu College of Science and Technology; and the Instrumental Analysis and Research Center of Shanghai University for their technological and instrumental support.

\section{References}

[1] B. Kang, G. Ceder, Nature, 458 (2009) 190-193.

[2] A.K. Padhi, K.S. Nanjundaswamy, J.B. Goodenough, J. Electrochem. Soc., 144 (1997) 1188-1194.

[3] S.Y. Chung, J.T. Bloking, Y.M. Chiang, Nat. Mater., 1 (2002) 123-128.

[4] P.S. Herle, B. Ellis, N. Coombs, L.F. Nazar, Nat. Mater., 3 (2004) 147-152.

[5] N. Ravet, A. Abouimrane, M. Armand, Nat. Mater., 2 (2003) 702-703.

[6] J.F. Ni, H.H. Zhou, J.T. Chen, X.X. Zhang, Mater. Lett., 59 (2005) 2361-2365.

[7] G.X. Wang, S. Needham, J. Yao, J.Z. Wang, R.S. Liu, H.K. Liu, J. Power Sources, 159 (2006) 282-286. 
[8] G. Meligrana, C. Gerbaldi, A. Tuel, S. Bodoardo, N. Penazzi, J. Power Sources, 160 (2006) 516-522.

[9] J.J. Chen, M.S. Whittingham, Hydrothermal synthesis of lithium iron phosphate, Electrochem, Commun. 8 (2006) 855-858.

[10] J.J. Chen, S.J. Wang, M.S. Whittingham, Hydrothermal synthesis of cathode materials, J. Power Sources 174 (2007) 442-448.

[11] K. Dokko, S. Koizumi, K. Sharaishi, K. Kanamura, Electrochemical properties of $\mathrm{LiFePO}_{4}$ prepared via hydrothermal route, J. Power Sources 165 (2007) 656-659.

[12] J.J. Chen, M.J. Vacchio, S.J. Wang, N. Chernova, P.Y. Zavalij, M.S. Whittingham, The hydrothermal synthesis and characterization of olivines and related compounds for electrochemical applications, Solid State Ionics 178 (2008) 1676-1693.

[13] J.J. Chen, J.Graetz, Study of Antisite Defects in Hydrothermally Prepared $\mathrm{LiFePO}_{4}$ by in Situ X-ray Diffraction, ACS Appl. Mater. Interfaces 3 (2011) 1380-1384.

[14] J.J. Chen, J.M. Bai, H.Y. Chen, J. Graetz, In Situ Hydrothermal Synthesis of $\mathrm{LiFePO}_{4}$ Studied by Synchrotron X-ray Diffraction, J. Phys. Chem. Lett. 2 (2011) 1874-1878.

[15] J.J. Chen, A Review of Nanostructured Lithium Ion Battery Materials via Low Temperature Synthesis, Recent Pat. Nanotechnol. 7 (2013) 2-12.

[16] J.J. Chen, Recent Progress in Advanced Materials for Lithium Ion Batteries, Materials 6 (2013) 156-183.

[17] A.Y. Shenouda, H.K. Liu, J. Alloys Compd., 477 (2009) 498-503.

[18] N. Hua, C.Y. Wang, X.Y. Kang, Tuerdi, Y. Han, J. Inorg. Mater., 25 (2010) 887-892.

[19] Y. Cui, X. Zhao, R. Guo, Mater. Res. Bull., 45 (2010) 844-849.

[20] L. Dake, D. Baer, J. Zachara, Surf. Interface Anal., 14 (1989) 71-75.

[21] S.W. Gaarenstroom, N. Winograd, J. Chem. Phys., 67 (1977) 3500-3506.

[22] C. Wagner, Faraday Discuss. Chem. Soc., 60 (1975) 291-300.

[23] J.C. Arrebola, A. Caballero, L. Hernan, J. Morales, J. Power Sources, 195 (2010) 4278-4284.

[24] M. Higuchi, K. Katayama, Y. Azuma, M. Yukawa, M. Suhara, J. Power Sources, 119 (2003) 258-261.

[25] J.-K. Kim, J.-W. Choi, G.S. Chauhan, J.-H. Ahn, G.-C. Hwang, J.-B. Choi, H.-J. Ahn, Electrochim. Acta, 53 (2008) 8258-8264.

[26] S. Yang, X. Zhou, J. Zhang, Z. Liu, J. Mater. Chem., 20 (2010) 8086-8091.

[27] K. Saravanan, P. Balaya, M.V. Reddy, B.V.R. Chowdari, J.J. Vittal, Energ. Environ. Sci., 3 (2010) $457-464$.

[28] E. Zhecheva, M. Mladenov, P. Zlatilova, V. Koleva, R. Stoyanova, J. Phys. Chem. Solids, 71 (2010) 848-853.

[29] C. Zhu, Y. Yu, L. Gu, K. Weichert, J. Maier, Angew. Chem. Int. Ed., 50 (2011) 6278-6282.

[30] O. Waser, R. Buechel, A. Hintennach, P. Novak, S.E. Pratsinis, J. Aerosol Sci, 42 (2011) 657-667.

[31] J. Lim, D. Kim, V. Mathew, D. Ahn, J. Kang, S.-W. Kang, J. Kim, J. Alloys Compd., 509 (2011) 8130-8135.

[32] J. Orlenius, O. Lyckfeldt, K.A. Kasvayee, P. Johander, J. Power Sources, 213 (2012) 119-127.

[33] F. Croce, A. D'Epifanioa, J. Hassoun, A. Deptula, T. Olczac, B. Scrosati, Electrochem. Solid S.T., 5 (2002) A47-A50.

[34] D. Andre, M. Meiler, K. Steiner, H. Walz, T. Soczka-Guth, D.U. Sauer, J. Power Sources, 196 (2011) 5349-5356. 
[35] N.S. Zhai, M.W. Li, W.L. Wang, D.L. Zhang, D.G. Xu, in: J. Tan (Eds.), 4th International Symposium on Instrumentation Science and Technology, 2006, pp. 1157-1161. 


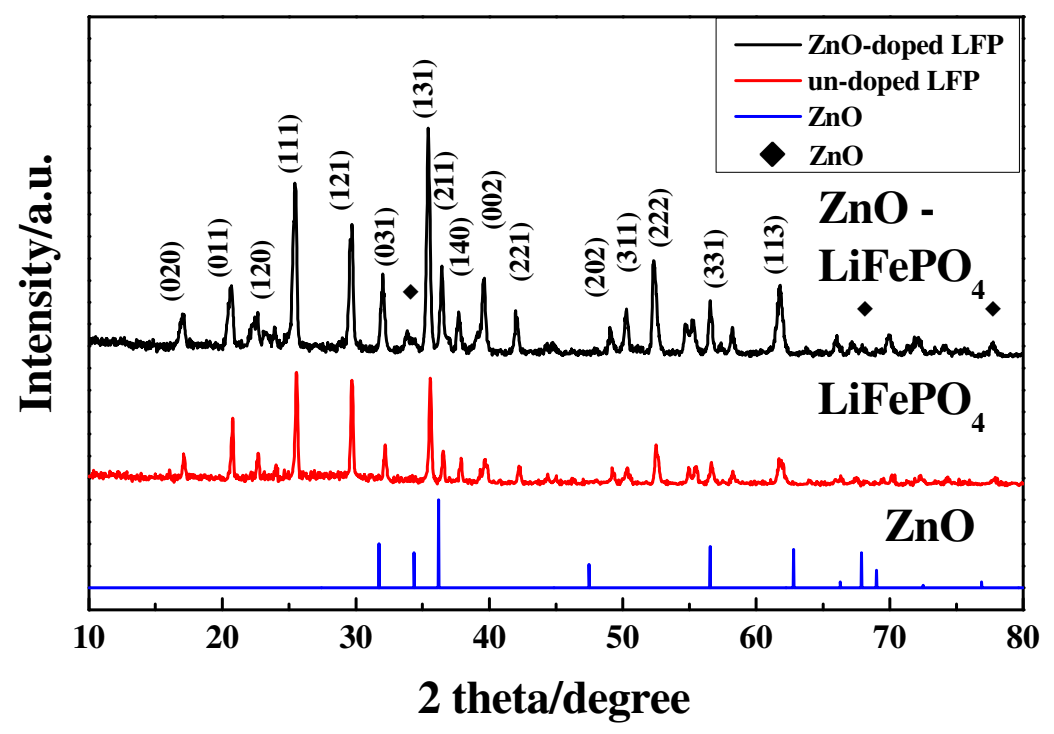

Figure 1 


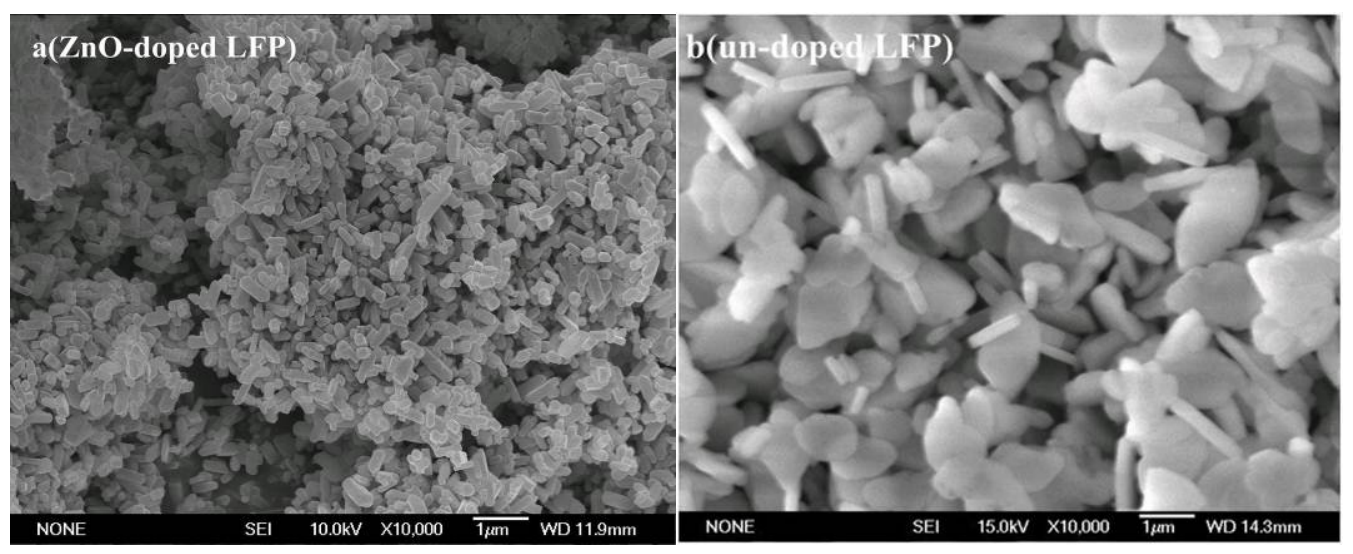

Figure 2 

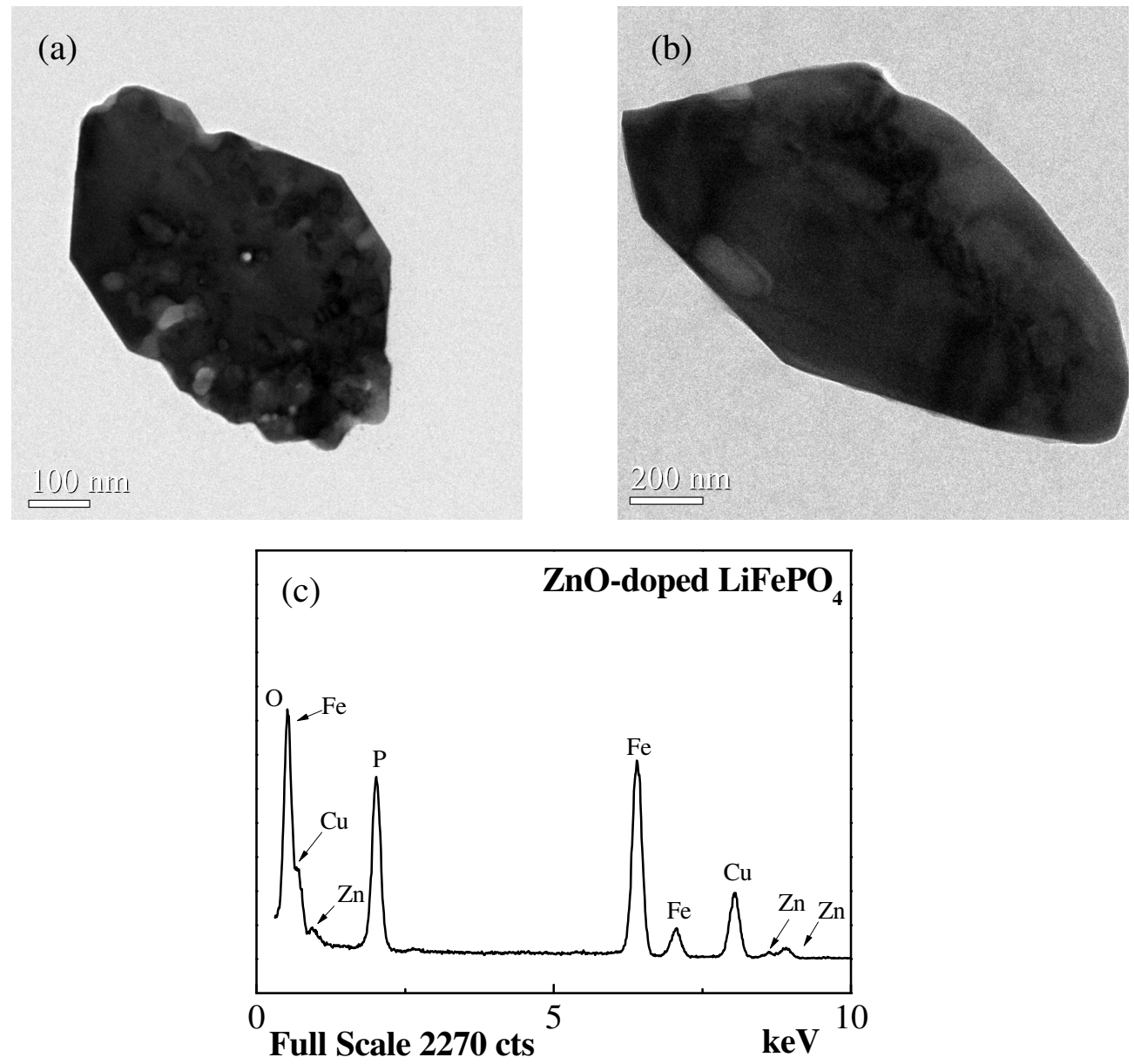

Figure 3 

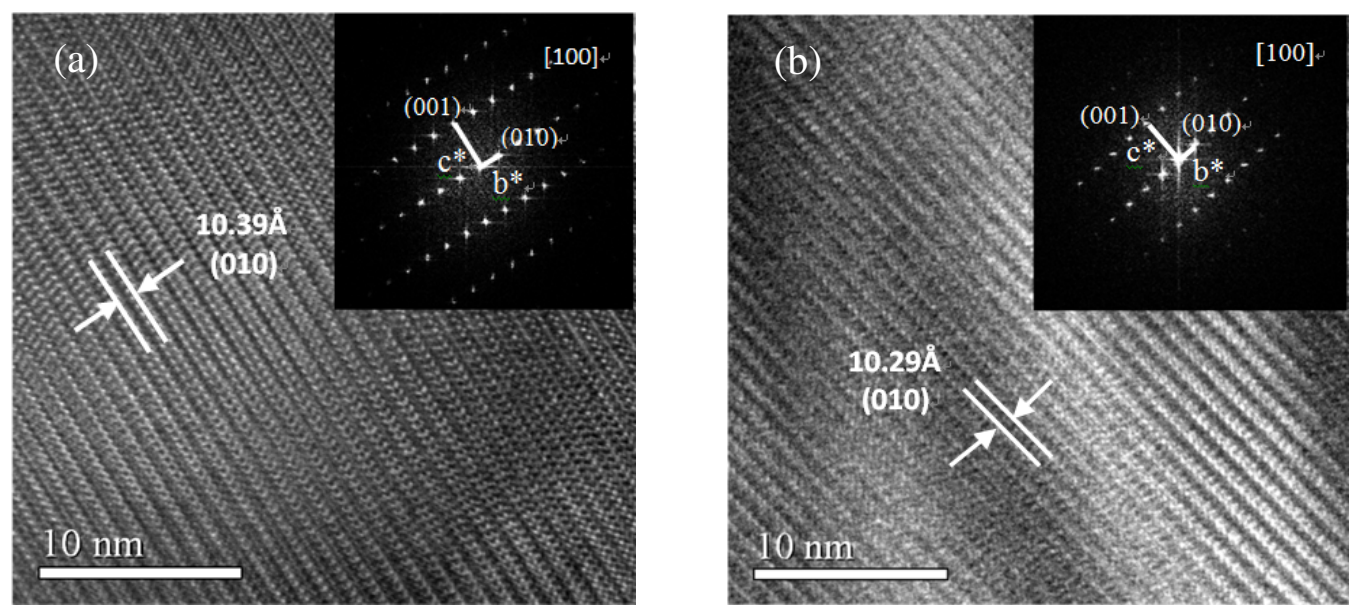

Figure 4 

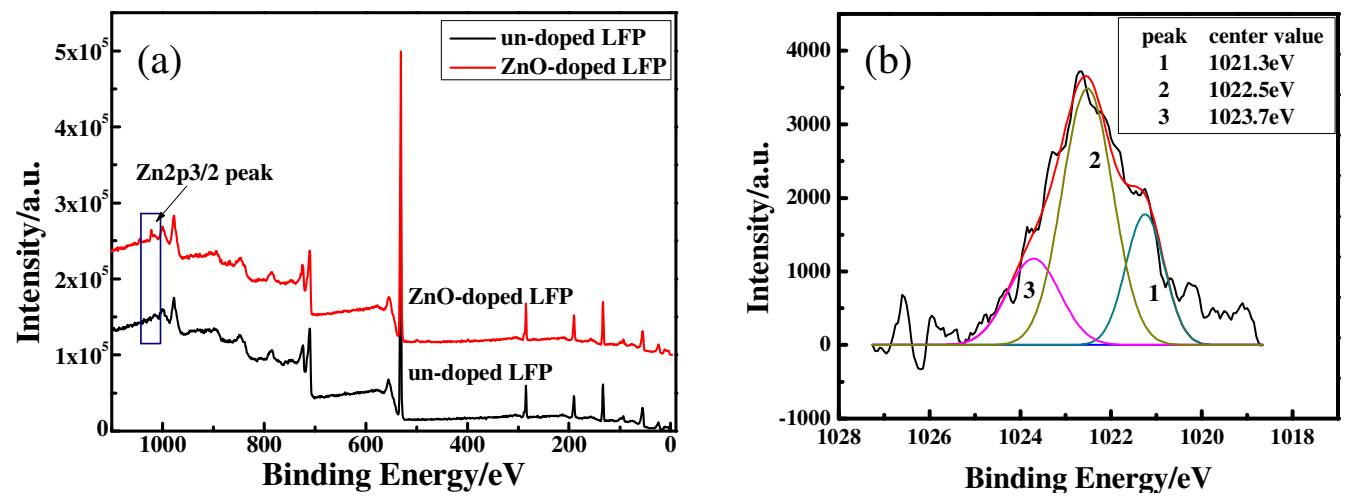

Figure 5 


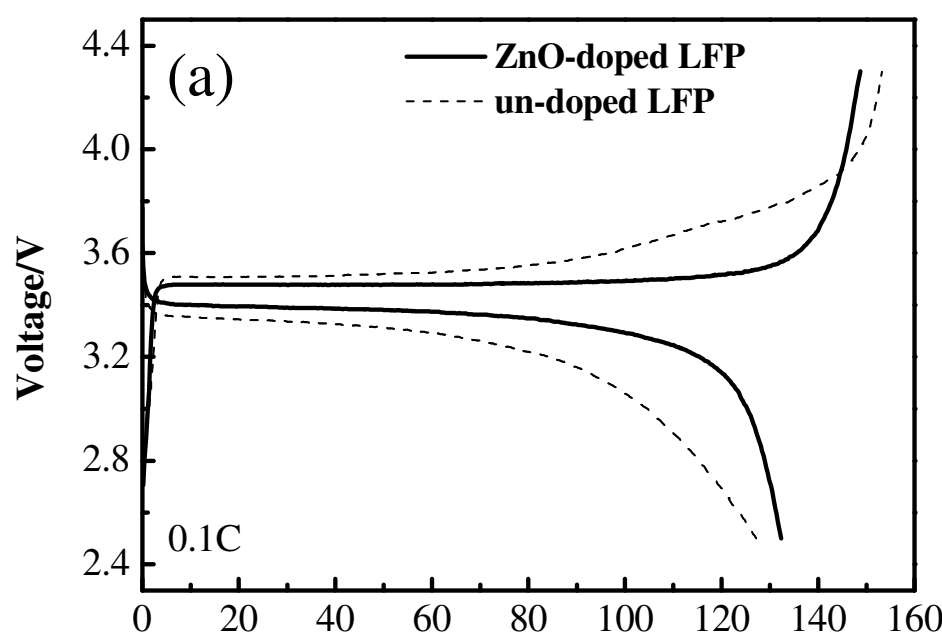

Capacity/mAh/g

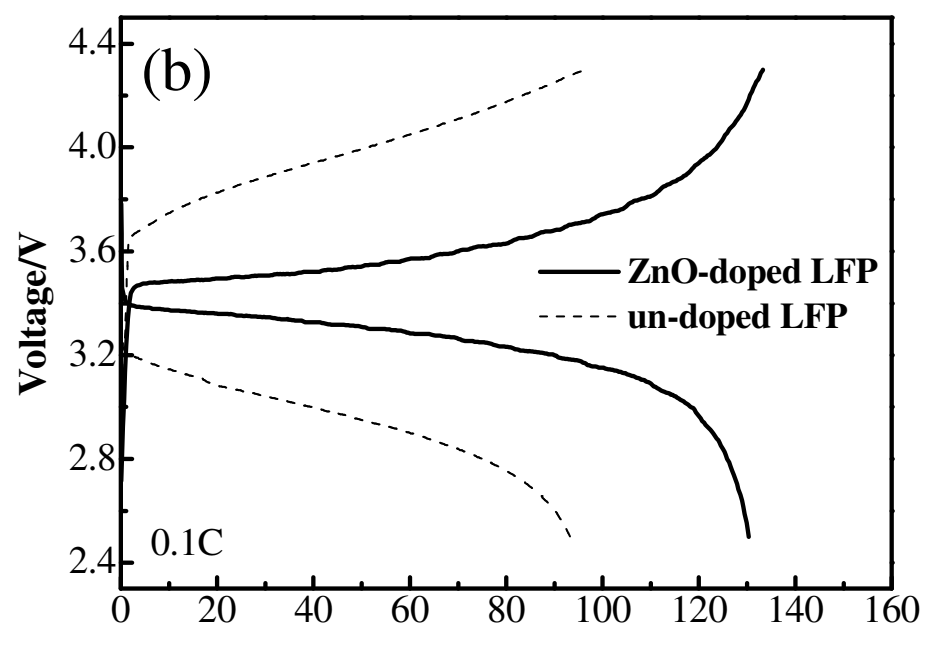

Capacity/mAh/g

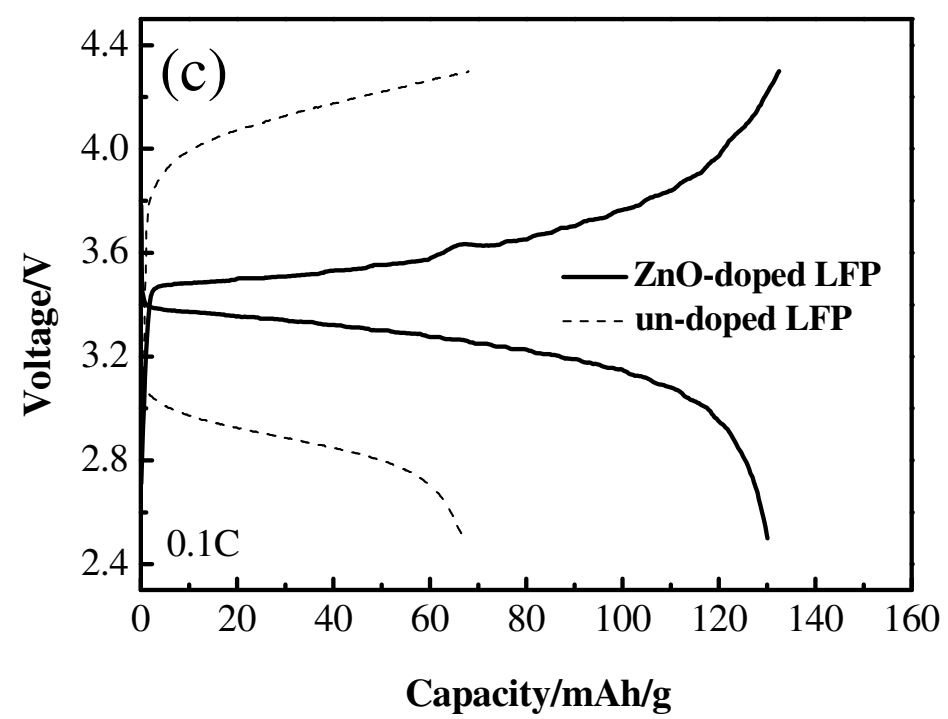

Figure 6 


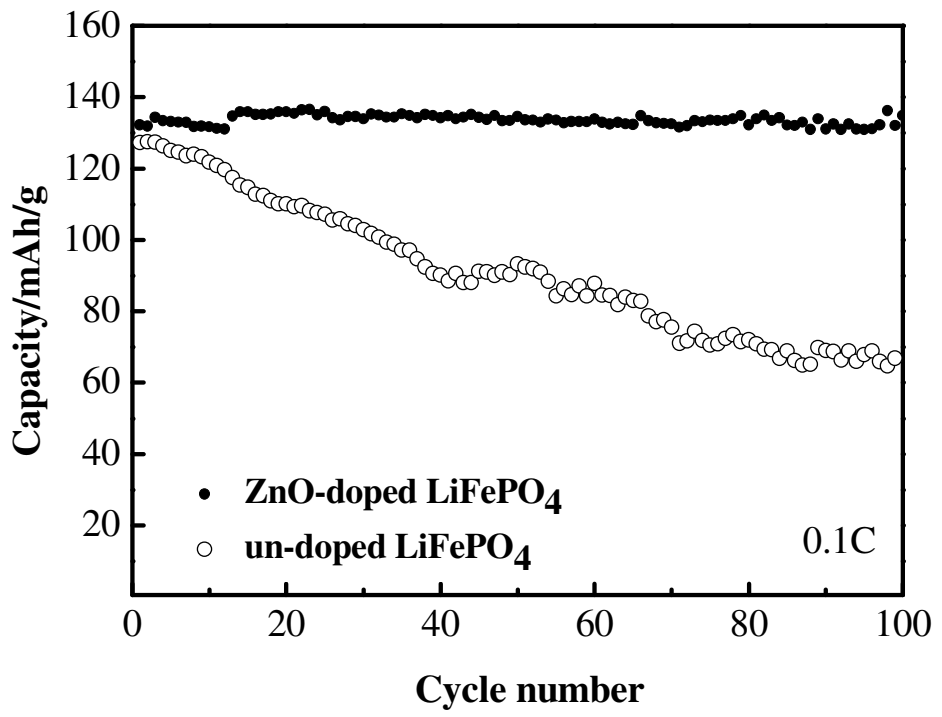

Figure 7 


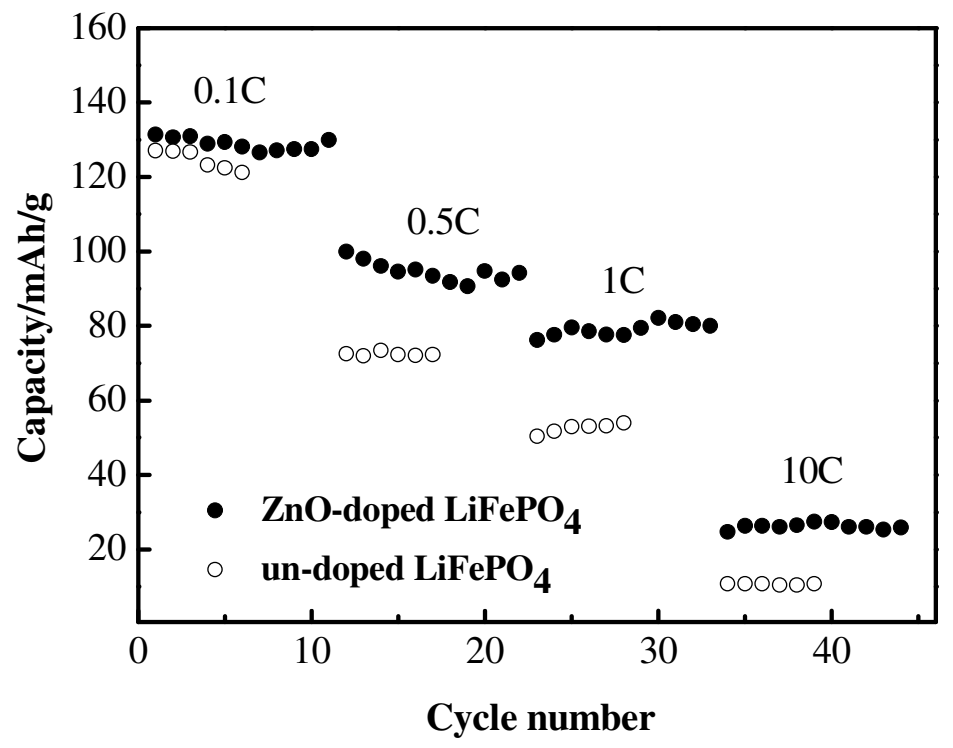

Figure 8 


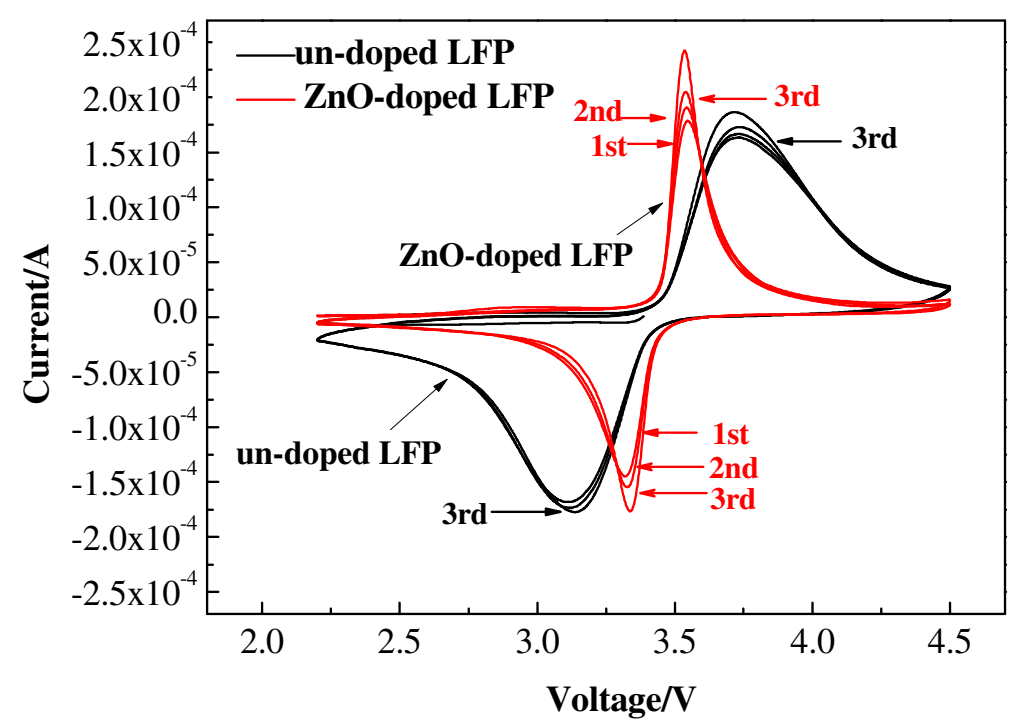

Figure 9 


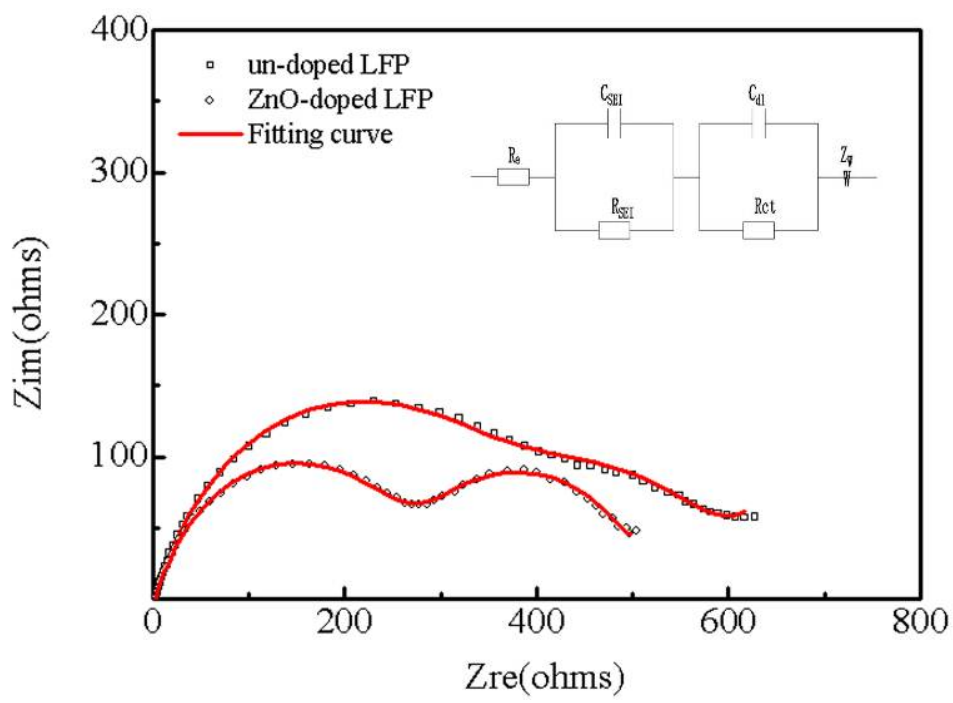

Figure 10 


\section{Figure Captions}

1. Fig.1 XRD patterns of $\mathrm{ZnO}$-doped and un-doped $\mathrm{LiFePO}_{4}$.

2. Fig.2 SEM images (a) ZnO-doped LFP image (b) un-dpoed LFP image.

3. Fig.3 TEM micrograph of (a) $\mathrm{ZnO}$-doped $\mathrm{LiFePO}_{4}$, (b) un-doped $\mathrm{LiFePO}_{4}$, (c) EDS spectrum of $\mathrm{ZnO}$-doped $\mathrm{LiFePO}_{4}$.

4. Fig.4 HRTEM images and FFT patterns of (a) ZnO-doped $\mathrm{LiFePO}_{4}$ and (b) un-doped $\mathrm{LiFePO}_{4}$.

5. Fig.5 XPS analysis graph (a) XPS spectra of $\mathrm{ZnO}$-doped $\mathrm{LiFePO}_{4}$ and (b) XPS fitting curves of $\mathrm{Zn} 2 \mathrm{p} 3 / 2$ scope for $\mathrm{ZnO}$-doped $\mathrm{LiFePO}_{4}$.

6. Fig.6 Curves of charge-discharge capacities at $0.1 \mathrm{C}-$ rate, (a) $1^{\text {st }}$, (b) $50^{\text {th }}$ and (c) $100^{\text {th }}$ cycles.

7. Fig.7 Cycle performance at $0.1 \mathrm{C}$-rate.

8. Fig.8 Cycle performance at various C-rates (0.1C, 0.5C, 1C, 10C).

9. Fig.9 $\mathrm{C}-\mathrm{V}$ curves tested at $0.1 \mathrm{mV} \cdot \mathrm{s}^{-1}$ between $2.3 \mathrm{~V}$ and $4.5 \mathrm{~V}$.

10. Fig.10 Electrochemical impedance spectra of the samples and the equivalent circuit model. 


\section{Table 1}

\begin{tabular}{|c|c|c|c|c|c|c|c|c|c|}
\hline \multicolumn{6}{|c|}{$\mathrm{X}$ - ray diffractions } & \multicolumn{4}{|c|}{ fast Fourier transformation } \\
\hline Samples & $\mathrm{a}(\AA)$ & $\mathrm{b}(\AA)$ & $c(\AA)$ & $\mathrm{b} / \mathrm{c}$ & $\begin{array}{c}\text { volume } \\
\left(\AA^{3}\right) \\
\end{array}$ & $b^{*}(1 / \mathrm{nm})$ & $\mathrm{b}(\AA)$ & $c^{*}(1 / \mathrm{nm})$ & $\mathrm{b} / \mathrm{c}$ \\
\hline ZnO-doped & 5.995 & 10.361 & 4.704 & 2.203 & 292.19 & 0.9607 & 10.39 & 2.1070 & 2.19 \\
\hline un-doped & 5.991 & 10.299 & 4.682 & 2.200 & 288.89 & 0.9716 & 10.29 & 2.1093 & 2.17 \\
\hline
\end{tabular}


Table 2

\begin{tabular}{cccc}
\hline & Position (eV) & FWHM (eV) & Amount Percentage (at.\%) \\
\hline Peak1 & 1021.3 & 1.000 & 22.343 \\
Peak2 & 1022.5 & 1.313 & 57.545 \\
Peak3 & 1023.7 & 1.363 & 20.112 \\
\hline
\end{tabular}


Table 3

\begin{tabular}{|c|c|c|c|c|c|}
\hline Author & $\begin{array}{l}\text { Synthesis } \\
\text { Method }\end{array}$ & $\begin{array}{c}\text { Initial } \\
\text { Capacity } \\
(\mathrm{mAh} / \mathrm{g})\end{array}$ & Cyclic Performance & $\begin{array}{c}\text { Modification } \\
\text { Treatment }\end{array}$ & $\begin{array}{l}\text { Publicati } \\
\text { on Year }\end{array}$ \\
\hline $\begin{array}{l}\text { Our group } \\
\text { [this paper] }\end{array}$ & Hydrothermal & $132.3(0.1 \mathrm{C})$ & $\begin{array}{c}100 \text { cycles, } 129.9 \\
\mathrm{mAh} / \mathrm{g}, 98.2 \%(0.1 \mathrm{C}) \\
80 \mathrm{mAh} / \mathrm{g}, 60.5 \%(1 \mathrm{C})\end{array}$ & $\begin{array}{l}\text { Doped with } \\
\mathrm{ZnO}\end{array}$ & \\
\hline $\begin{array}{l}\text { M. Higuchi } \\
{[24]}\end{array}$ & Microwave & $125(0.1 \mathrm{C})$ & $\begin{array}{c}20 \text { cycles, } \quad 85 \mathrm{mAh} / \mathrm{g}, \\
68 \%(0.1 \mathrm{C})\end{array}$ & None & 2003 \\
\hline $\begin{array}{l}\text { J.H. Ahn } \\
\text { [25] }\end{array}$ & $\begin{array}{l}\text { Sol-gel + heat } \\
\text { treatment }\end{array}$ & $152(0.1 \mathrm{C})$ & $\begin{array}{c}100 \text { cycles, } 146 \\
\mathrm{mAh} / \mathrm{g}, \quad 96 \%(1 \mathrm{C})\end{array}$ & $\begin{array}{l}\text { Carbon } \\
\text { coating }\end{array}$ & 2008 \\
\hline $\begin{array}{c}\text { H.K. Liu } \\
\text { [17] }\end{array}$ & Ball milling & $\left.\begin{array}{c}125(20 \mathrm{~mA} / \mathrm{cm} \\
2\end{array}\right)$ & $\begin{array}{c}150 \text { cycles, } 100 \mathrm{mAh} / \mathrm{g} \\
80 \%\left(20 \mathrm{~mA} / \mathrm{cm}^{2}\right)\end{array}$ & $\begin{array}{l}\text { Mixed with } \\
\text { ZnO }\end{array}$ & 2009 \\
\hline $\begin{array}{l}\text { Z. P. Liu } \\
\text { [26] }\end{array}$ & Solvothermal & $155(0.1 \mathrm{C})$ & $\begin{array}{c}1000 \text { cycles, } 126 \mathrm{mAh} / \mathrm{g}, \\
89 \%(20 \mathrm{C},)\end{array}$ & $\begin{array}{l}\text { Carbon } \\
\text { coating }\end{array}$ & 2010 \\
\hline $\begin{array}{l}\text { P. Balaya } \\
\text { [27] }\end{array}$ & Solvothermal & $167(0.1 \mathrm{C})$ & $\begin{array}{c}50 \text { cycles, } 167 \mathrm{mAh} / \mathrm{g} \\
100 \%(0.1 \mathrm{C})\end{array}$ & $\begin{array}{l}\text { Carbon } \\
\text { coating }\end{array}$ & 2010 \\
\hline $\begin{array}{c}\mathrm{R} . \\
\text { Stoyanova } \\
{[28]}\end{array}$ & $\begin{array}{l}\text { Freeze drying + } \\
\quad \text { solid state }\end{array}$ & $130(0.1 \mathrm{C})$ & $\begin{array}{c}85 \text { cycles, } 108 \mathrm{mAh} / \mathrm{g}, \\
83 \%(0.1 \mathrm{C})\end{array}$ & $\begin{array}{l}\text { Carbon } \\
\text { coating }\end{array}$ & 2010 \\
\hline Y. Yu [29] & Electrospinning & $169(0.1 \mathrm{C})$ & $\begin{array}{c}100 \text { cycles, } 146 \mathrm{mAh} / \mathrm{g} \\
86 \%(1 \mathrm{C})\end{array}$ & $\begin{array}{l}\text { Carbon } \\
\text { coating }\end{array}$ & 2011 \\
\hline $\begin{array}{c}\text { S. E. } \\
\text { Pratsinis } \\
{[30]}\end{array}$ & $\begin{array}{c}\text { Flame aerosol + } \\
\text { solid state }\end{array}$ & $163(0.5 \mathrm{C})$ & $\begin{array}{c}200 \text { cycles, } 158 \\
\mathrm{mAh} / \mathrm{g}, \quad 97 \%(2 \mathrm{C})\end{array}$ & $\begin{array}{l}\text { Carbon } \\
\text { coating }\end{array}$ & 2011 \\
\hline J. Kim [31] & $\begin{array}{l}\text { Solid state } \\
\text { synthesis }\end{array}$ & $\begin{array}{c}150(0.1 \mathrm{~mA} / \mathrm{c} \\
\left.\mathrm{m}^{2}\right)\end{array}$ & $\begin{array}{c}50 \text { cycles, } 135 \mathrm{mAh} / \mathrm{g}, \\
90 \%\left(0.1 \mathrm{~mA} / \mathrm{cm}^{2}\right)\end{array}$ & $\begin{array}{l}\text { Carbon } \\
\text { coating }\end{array}$ & 2011 \\
\hline $\begin{array}{c}\text { O. } \\
\text { Lyckfeldt } \\
{[32]}\end{array}$ & $\begin{array}{c}\text { Freeze } \\
\text { granulation } \\
\text { +solid state }\end{array}$ & $141(0.1 \mathrm{C})$ & $\begin{array}{c}200 \text { cycles, } 107 \mathrm{mAh} / \mathrm{g}, \\
94 \%(1 \mathrm{C})\end{array}$ & $\begin{array}{l}\text { Carbon } \\
\text { coating }\end{array}$ & 2012 \\
\hline
\end{tabular}


Table 4

\begin{tabular}{ccccccc}
\hline \multirow{2}{*}{ Cells } & $\mathrm{R}_{\mathrm{e}}$ & $\mathrm{C}_{\mathrm{SEI}}$ & $\mathrm{R}_{\mathrm{SEI}}$ & $\mathrm{C}_{\mathrm{dl}}$ & $\mathrm{R}_{\mathrm{ct}}$ & $\mathrm{Z}_{\mathrm{w}}$ \\
\cline { 2 - 7 } & {$[\Omega]$} & {$\left[\times 10^{-4} \mathrm{~F}\right]$} & {$[\Omega]$} & {$\left[\times 10^{-4} \mathrm{~F}\right]$} & {$[\Omega]$} & {$[\Omega]$} \\
\hline un-doped & 0.565 & 6.398 & 59.300 & 0.272 & 87.325 & 0.017 \\
ZnO-doped & 0.586 & 14.538 & 43.825 & 0.345 & 53.925 & 0.040 \\
\hline
\end{tabular}




\section{Table Captions}

1. Table 1 Lattice parameters of $\mathrm{ZnO}$-doped and un-doped $\mathrm{LiFePO}_{4}$ obtained by different analysis methods (Pnmb space group)

2. Table 2 XPS quantitative analysis results of $\mathrm{Zn}$ ( II ) ions

3. Table 3 Comparison with the high performance $\mathrm{LiFePO}_{4}$ published in recent years

4. Table 4 Impedance parameters evaluated from the EIS data by using equivalent circuit 